\title{
Phytochemicals in the treatment of hyperpigmentation
}

\author{
This article was published in the following Dove Press journal: \\ Botanics:Targets and Therapy \\ 16 September 2016 \\ Number of times this article has been viewed
}

\author{
Ashley K Clark' \\ Raja K Sivamani² \\ 'University of California, Davis \\ School of Medicine, ${ }^{2}$ Department \\ of Dermatology, University of \\ California - Davis, Sacramento, \\ CA, USA
}

Correspondence: Raja K Sivamani Department of Dermatology, University of California - Davis, 330I C Street, Suite 1400, Sacramento, CA 95816, USA

Tel +19167035145

Fax +19167817183

Email rksivamani@ucdavis.edu
Abstract: Treating hyperpigmentation can be challenging and an expanded arsenal is needed to aid in the improvement of topical treatments. The current gold standard treatment is hydroquinone. However, it has been associated with a number of adverse effects, including skin irritation, contact dermatitis, and exogenous ochronosis in people of darker complexion. Cosmeceuticals are topical cosmetic-pharmaceutical hybrids containing biologically active ingredients that may improve the appearance of skin and are increasingly popular alternatives to standard agents. Among cosmeceuticals, plant derived compounds, known as phytochemicals, have been shown to have a multitude of cellular actions for various dermatological diseases. This review examines the latest clinical studies using plant-derived compounds and their effectiveness in the management of hyperpigmentation disorders.

Keywords: phytochemicals, botanical, hyperpigmentation, melasma, lentigines

\section{Introduction}

Hyperpigmentation is a common dermatologic condition among patients of all skin types. Pigmentation disorders are the third most common among dermatologic disorders and cause significant psychosocial impairment. ${ }^{1}$ Common hyperpigmentation disorders include melasma, solar lentigines, and postinflammatory hyperpigmentation, which result from many skin conditions, including acne, eczema, contact dermatitis, or trauma. These disorders and damages caused by ultraviolet (UV) light are generally difficult to treat and a variety of products exist ranging from prescription, over-thecounter, to cosmeceuticals.

The gold standard topical treatment for hyperpigmentation is hydroquinone, a hydroxyphenolic chemical. ${ }^{2}$ However, it has been associated with a number of adverse effects, including skin irritation, contact dermatitis, and exogenous ochronosis in people of darker complexion. ${ }^{3}$ Furthermore, its adverse effects have led to its removal from cosmetics in multiple countries, including those of the European Union. ${ }^{4}$ Although hydroquinone has not been shown to increase carcinogenesis in humans, the perceived safety concerns regarding its use have increased the demand for alternative safe and efficacious skin-lightening agents. The search for novel lightening agents has led to the investigation of natural plant extracts. Many of the active plant compounds may be more potent inhibitors of melanin formation than hydroquinone and may not be associated with the same cytotoxicity. ${ }^{3}$

Cosmeceuticals are topical cosmetic-pharmaceutical hybrids ${ }^{5}$ containing biologically active ingredients that may have a beneficial effect due to possible pharmacological 
Phytochemical

Aleosin

Alpha-bisabolol

Arbutin

Ellagic acid

Glabridin

Figure I Phytochemicals

actions that may improve the appearance of the skin and are increasingly popular alternatives to standard depigmenting agents. ${ }^{6,7}$ Increasingly, patients are turning away from prescription medications and medical procedures in search of cost-effective noninvasive methods. ${ }^{7}$ Cosmeceuticals are attractive alternatives as they are often inexpensive and
Phytochemical

Hesperidin<smiles>COc1ccc([C@H]2CC(=O)c3c(O)cc(O[C@@H]4O[C@H](CO[C@H]5O[C@@H](C)[C@H](O)[C@H](O)[C@H]5O)[C@@H](O)[C@H](O)[C@H]4O)cc3O2)cc1O</smiles>

Liquiritin<smiles>O=C1C[C@H](c2ccc(O[C@@H]3O[C@H](CO)[C@@H](O)[C@H](O)[C@H]3O)cc2)Oc2cc(O)ccc21</smiles>

Procyanidin<smiles>Oc1cc(O)c2c(c1)OC(c1ccc(O)c(O)c1)C(OC1(c3ccc(O)c(O)c3)Oc3cc(O)cc(O)c3C(O)C1O)C2</smiles>

Silymarin<smiles>COc1cc([C@H]2Oc3cc([C@H]4Oc5cc(O)cc(O)c5C(=O)[C@H]4O)ccc3O[C@H]2CO)ccc1O</smiles>

easily available over-the-counter. ${ }^{8}$ Among cosmeceuticals, plant-derived compounds, known as phytochemicals, have been shown to have a multitude of cellular actions for various dermatological diseases (Figure 1). ${ }^{9-12}$ In clinical practice, patients will seek a dermatologist's advice on the beneficial effects of phytochemical products. Accurate advice on the 
Table I Overview of clinical studies of botanical extracts

\begin{tabular}{|c|c|c|c|c|c|c|c|}
\hline $\begin{array}{l}\text { Botanical } \\
\text { component }\end{array}$ & $\begin{array}{l}\text { Plant } \\
\text { source }\end{array}$ & $\begin{array}{l}\text { Depigmenting } \\
\text { mechanism }\end{array}$ & $\begin{array}{l}\text { Pigment } \\
\text { disorder }\end{array}$ & Comparison & Major results & Limitations & $\begin{array}{l}\text { Author, } \\
\text { year }\end{array}$ \\
\hline Aloesin & Aloe vera & $\begin{array}{l}\text { Competitively } \\
\text { inhibit } \\
\text { tyrosinase, } \\
\text { decrease } \\
\text { DOPA oxidase }\end{array}$ & $\begin{array}{l}\text { UV radiation } \\
\text { hyperpigmentation }\end{array}$ & $\begin{array}{l}\text { 1) Vehicle } \\
\text { control } \\
\text { 2) Arbutin } \\
\text { treated } \\
\text { 3) Aloesin and } \\
\text { arbutin } \\
\text { treated }\end{array}$ & $\begin{array}{l}\text { I) Aloesin treatment } \\
\text { suppressed } \\
\text { pigmentation by } 34 \% \\
\text { 2) Arbutin by } 43.5 \% \\
\text { 3) Cotreatment by } \\
63.3 \% \text { compared with } \\
\text { the control } \\
\text { 4) Aleosin treatment } \\
\text { showed pigmentation } \\
\text { suppression in a } \\
\text { dose-dependent } \\
\text { manner }(P<0.05)\end{array}$ & $\begin{array}{l}\text { I) No between } \\
\text { group comparison } \\
\text { done }\end{array}$ & $\begin{array}{l}\text { Choi et al, }{ }^{15} \\
2002\end{array}$ \\
\hline Alpha-bisabolol & Chamomile & $\begin{array}{l}\text { Inhibits alpha- } \\
\text { MSH-induced } \\
\text { melanogenesis } \\
\text { by suppressing } \\
\text { cAMP }\end{array}$ & $\begin{array}{l}\text { UVA and UVB } \\
\text { tanned skin } \\
\text { (with solar } \\
\text { simulator) }\end{array}$ & Vehicle cream & $\begin{array}{l}\text { I) Significantly } \\
\text { effective lightening } \\
\text { as measured by } \\
\text { spectrophotometer } \\
\text { than vehicle control } \\
\text { 2) No difference } \\
\text { between groups } \\
\text { detected by clinical } \\
\text { evaluation }\end{array}$ & $\begin{array}{l}\text { I) Lightening effect } \\
\text { measured with } \\
\text { spectrophotometer } \\
\text { not detected in clinical } \\
\text { evaluation } \\
\text { 2) No description } \\
\text { of clinical evaluation } \\
\text { criteria }\end{array}$ & $\begin{array}{l}\text { Lee et al, }{ }^{16} \\
2010\end{array}$ \\
\hline Arbutin & $\begin{array}{l}\text { Bearberry, } \\
\text { California } \\
\text { buckeye, } \\
\text { cranberry, } \\
\text { and blueberry }\end{array}$ & $\begin{array}{l}\text { Inhibit } \\
\text { tyrosinase, } \\
\text { and DHICA } \\
\text { polymerase }\end{array}$ & Solar lentigines & Vehicle control & $\begin{array}{l}\text { The results of } \\
\text { the clinical study } \\
\text { demonstrated that } \\
\text { arbutin provided a } \\
\text { significant effect on } \\
\text { overall skin lightening } \\
\text { and moderate } \\
\text { resolution of solar } \\
\text { lentigines in Caucasian } \\
\text { subjects }\end{array}$ & $\begin{array}{l}\text { The test period } \\
\text { for the study was } \\
\text { from November to } \\
\text { February, a period } \\
\text { when complexion } \\
\text { coloration generally } \\
\text { lightens in the } \\
\text { Northern Hemisphere }\end{array}$ & $\begin{array}{l}\text { Boissy } \\
\text { et al, }{ }^{20} 2005\end{array}$ \\
\hline Ellagic acid & $\begin{array}{l}\text { Green tea, } \\
\text { strawberry, } \\
\text { geranium, } \\
\text { grapes, } \\
\text { cherries, } \\
\text { and walnuts }\end{array}$ & $\begin{array}{l}\text { Copper } \\
\text { chelation, } \\
\text { decrease } \\
\text { melanocyte } \\
\text { proliferation }\end{array}$ & Melasma & $\begin{array}{l}\text { 1) Arbutin } \\
\text { 2) Synthetic } \\
\text { ellagic acid }\end{array}$ & $\begin{array}{l}\text { Significant } \\
\text { improvement in } \\
\text { pigment density in } \\
\text { all groups, with no } \\
\text { statistical difference } \\
\text { between them }\end{array}$ & $\begin{array}{l}\text { Plant-derived ellagic } \\
\text { acid not studied } \\
\text { independently } \\
\text { (treatment group } \\
\text { received combination } \\
\text { of synthetic and plant- } \\
\text { derived ellagic acid) }\end{array}$ & $\begin{array}{l}\text { Ertam } \\
\text { et al, }{ }^{21} 2008\end{array}$ \\
\hline Glabridin & Licorice & $\begin{array}{l}\text { Inhibit } \\
\text { tyrosinase }\end{array}$ & $\begin{array}{l}\text { UVB-induced } \\
\text { pigmentation }\end{array}$ & None & $\begin{array}{l}\text { UVB-induced } \\
\text { pigmentation and } \\
\text { erythema in the skins } \\
\text { of guinea pigs were } \\
\text { inhibited by topical } \\
\text { applications of } 0.5 \% \\
\text { glabridin }\end{array}$ & $\begin{array}{l}\text { Application on human } \\
\text { skin and } \\
\text { effects are unknown }\end{array}$ & $\begin{array}{l}\text { Yokota } \\
\text { et al, }{ }^{24} 1998\end{array}$ \\
\hline \multirow[t]{2}{*}{ Hesperidin } & $\begin{array}{l}\text { Citrus } \\
\text { fruits }\end{array}$ & $\begin{array}{l}\text { Inhibit } \\
\text { tyrosinase, } \\
\text { antioxidant of } \\
\text { collagen }\end{array}$ & $\begin{array}{l}\text { In vitro, human } \\
\text { melanocytes }\end{array}$ & None & $\begin{array}{l}\text { Photoprotective effect } \\
\text { was obtained after } \\
\text { hesperetin cream } \\
\text { topical application } \\
\text { when compared to the } \\
\text { nontreatment group }\end{array}$ & $\begin{array}{l}\text { Enhancers were } \\
\text { added, and hesperidin } \\
\text { was not studied } \\
\text { independently }\end{array}$ & $\begin{array}{l}\text { Huang } \\
\text { et al, }{ }^{26} 2010\end{array}$ \\
\hline & & $\begin{array}{l}\text { Induce melanin } \\
\text { synthesis and } \\
\text { tyrosinase } \\
\text { activity }\end{array}$ & $\begin{array}{l}\text { In vitro, human } \\
\text { melanocytes }\end{array}$ & Control & $\begin{array}{l}\text { Compared to } \\
\text { control melanocytes, } \\
\text { increased melanin } \\
\text { production and } \\
\text { tyrosinase activity I.4- } \\
\text { fold }(P<0.0 \mathrm{I}) \text { and I.I -fold } \\
(P<0.0 \mathrm{I}) \text {, respectively }\end{array}$ & $\begin{array}{l}\text { Conflicting results } \\
\text { between studies }\end{array}$ & $\begin{array}{l}\text { Usach } \\
\text { et al, }{ }^{27} 2015\end{array}$ \\
\hline
\end{tabular}


Table I (Continued)

\begin{tabular}{|c|c|c|c|c|c|c|c|}
\hline $\begin{array}{l}\text { Botanical } \\
\text { component }\end{array}$ & $\begin{array}{l}\text { Plant } \\
\text { source }\end{array}$ & $\begin{array}{l}\text { Depigmenting } \\
\text { mechanism }\end{array}$ & $\begin{array}{l}\text { Pigment } \\
\text { disorder }\end{array}$ & Comparison & Major results & Limitations & $\begin{array}{l}\text { Author, } \\
\text { year }\end{array}$ \\
\hline Liquiritin & Licorice & $\begin{array}{l}\text { Melanin } \\
\text { dispersion, } \\
\text { epidermal } \\
\text { removal }\end{array}$ & Melasma & $4 \%$ hydroquinone & $\begin{array}{l}\text { Topical } 4 \% \text { liquiritin } \\
\text { is significantly more } \\
\text { effective than topical } \\
2 \% \text { liquiritin, and } \\
\text { topical } 2 \% \text { liquiritin is } \\
\text { also significantly more } \\
\text { effective than } \\
4 \% \text { hydroquinone }\end{array}$ & $\begin{array}{l}\text { Some patients used } \\
\text { sunscreen while } \\
\text { others did not. } \\
\text { This factor was not } \\
\text { considered in the } \\
\text { analysis of the results }\end{array}$ & $\begin{array}{l}\text { Zubair and } \\
\text { Mujtaba, }{ }^{28} \\
2009\end{array}$ \\
\hline Procyanidin & $\begin{array}{l}\text { Pinus } \\
\text { pinaster }\end{array}$ & $\begin{array}{l}\text { Antioxidant and } \\
\text { anti-inflammatory }\end{array}$ & Melasma & $\begin{array}{l}\text { Placebo } \\
\text { tablets } \\
\text { containing } \\
\text { starch }\end{array}$ & $\begin{array}{l}\text { Treatment group } \\
\text { with significantly } \\
\text { improved Mexameter } \\
\text { measurements and } \\
\text { MASI scores } \\
\text { compared with } \\
\text { placebo }\end{array}$ & $\begin{array}{l}\text { Procyanidin } \\
\text { treatment was } \\
\text { combined with } \\
\text { vitamins A, C, and } \\
\text { E and not studied } \\
\text { independently }\end{array}$ & $\begin{array}{l}\text { Handog } \\
\text { et al, }{ }^{30} 2009\end{array}$ \\
\hline Silymarin & $\begin{array}{l}\text { Silybum } \\
\text { marianum } \\
\text { (standardized } \\
\text { extract) }\end{array}$ & $\begin{array}{l}\text { Inhibit L-DOPA } \\
\text { oxidation activity } \\
\text { of tyrosinase }\end{array}$ & Melasma & Vehicle control & $\begin{array}{l}\text { I) All patients showed } \\
\text { significant pigment } \\
\text { improvement and } \\
\text { lesion size reduction. } \\
\text { 2) Effective in } \\
\text { prevention of skin } \\
\text { damage caused by UV } \\
\text { sunlight }\end{array}$ & $\begin{array}{l}\text { I) Patients advised } \\
\text { to use sunscreen } \\
\text { in addition to the } \\
\text { treatment cream, } \\
\text { possibly confounding } \\
\text { the results of the study }\end{array}$ & $\begin{array}{l}\text { Altaei, } \\
2012 \\
y\end{array}$ \\
\hline
\end{tabular}

Note: Data from Fisk et al ${ }^{8}$ and Zhu and Gao. ${ }^{3}$

Abbreviations: cAMP, cyclic adenosine monophosphate; DOPA, 3,4-dihydroxyphenylalanine, DHICA, 5,6-dihydroxyindole-2-carboxylic acid; L-DOPA, L-3,4,dihydroxyphenylalanine; MASI, Melasma Area and Severity Index; MSH, melanocyte-stimulating hormone; UV, ultraviolet; UVA, ultraviolet A; UVB, ultraviolet B.

benefits, side effects, and indications requires evidence-based knowledge. ${ }^{8}$ This review examines the latest evidence on the effectiveness of phytochemicals in the management of hyperpigmentation disorders (Table 1).

\section{Methods}

In April 2015, we searched EMBASE and Medline databases for published clinical studies examining the use of plantderived products for the treatment of hyperpigmentation. Search terms included "phytotherapy", "phytochemicals", "plant medicinal product", "herbal medicine", "herbaceous agent", and "hyperpigmentation". Studies involving plantderived compounds and pigmentation as an outcome measure were included. Bibliographies were searched for additional studies that met the inclusion criteria. Of the 152 articles, ten unique studies met the inclusion criteria (Table 1).

\section{Aleosin}

Aleosin is a moderately high molecular weight glycoprotein obtained from the Aloe vera plant. ${ }^{13}$ Aloe has been used for centuries in cosmetics, and the plant extracts, specifically aleosin, have been reported to inhibit L-3,4,-dihydroxyphenylalanine (L-DOPA) oxidation by mushroom and human tyrosinase. ${ }^{13,14}$ Aleosin is unique with its dual mechanism of inhibiting both mammalian and fungal tyrosinase. Additionally, it has a greater affinity for the DOPA oxidase catalytic site on tyrosinase in comparison to other botanicals such as arbutin and kojic acid. On the basis of these findings, Choi et $\mathrm{al}^{15}$ examined the inhibitory effect of aleosin treatment on the pigmentation of human skin induced by UV radiation. Aleosin treatment was found to inhibit hyperpigmentation after UV radiation in a dose-dependent manner. Reduction in pigmentation was objectively measured with a colorimeter. ${ }^{15}$ Cotreatment with aleosin and arbutin showed an additive effect. However, given the hydrophilic nature of the compound and its high molecular weight, penetration of the skin's stratum corneum is likely to be poor. With new drug delivery technology, there may be ways to study how enhancement of penetration may or may not affect its function as a depigmenting agent. ${ }^{13}$

\section{Alpha-bisabolol}

Alpha-bisabolol is a monocyclic sesquiterpene alcohol and the primary constituent of the Matricaria chamomilla plant. The compound has multiple properties, including anti-inflammatory, analgesic, antibiotic, and gastric protective agent. ${ }^{16}$ More recently, Kim et al ${ }^{17}$ studied the depigmenting activity of alpha-bisabolol and discovered that the compound inhibits 
alpha-melanocyte-stimulating hormone-induced melanogenesis by suppressing intracellular cyclic adenosine monophosphate levels. Given the in vitro studies, Lee et $\mathrm{al}^{16}$ evaluated the impact of alpha-bisabolol on hyperpigmented skin in a double-blind, vehicle-controlled trial. Over a 2-month period, 28 Korean female subjects, aged $32-52$ years, used $0.5 \%$ alphabisabolol-containing cream once a day and a vehicle control. With the assistance of a spectrophotometer as an objective measuring tool, the authors observed a stronger whitening effect in comparison to the vehicle control. ${ }^{16}$ However, the study has limitations, as the lightening effect was neither detected during clinical evaluation nor was there a description of the clinical evaluation criteria. Based on the in vitro and in vivo skin studies, alpha-bisabolol may be utilized as an adjunctive therapy for the reduction of hyperpigmentation.

\section{Arbutin}

Arbutin, hydroquinone- $O$ - $\beta$-D-glucopyranoside, is structurally related to hydroquinone. ${ }^{18}$ The ingredient is obtained from the leaves of the bearberry plant, from the fresh fruit of California buckeye, Aesculus californica (Spach) Nutt, and in lesser quantities from cranberry and blueberry leaves. The naturally occurring glucopyranoside acts to inhibit melanosomal tyrosinase and 5,6-dihydroxyindole-2-carboxylic acid polymerase activities at noncytotoxic concentrations. ${ }^{19}$ The activity of arbutin is driven by structural homology with the substrate tyrosine, which leads to the competitive inhibition of the catalytic function of tyrosinase. ${ }^{3}$ In an attempt to develop a more effective and safer tyrosinase inhibitor, Boissy et $\mathrm{al}^{20}$ synthesized deoxyarbutin, which demonstrated effective inhibition of mushroom tyrosinase in vitro. Subsequently, the authors conducted a 12-week double-blind clinical trial treating 50 postmenopausal females with solar lentigines using topical deoxyarbutin. For the assessment of improvement in solar lentigines, digital images were obtained, coded (using a 0-4 comparative scale), and evaluated side-by-side by three independent expert judges. The study resulted in a slight reduction in the overall skin lightness and improvement of solar lentigines in a population of light-skinned and dark-skinned individuals. ${ }^{20}$ One potential confounder was that the study was conducted during November to February, a period when complexion coloration usually lightens in the Northern Hemisphere.

\section{Ellagic acid}

Ellagic acid (EA) is a polyphenol phytochemical that can be found in certain plants in nature and in some nutrients such as green tea, strawberry, geranium, grapes, cherries, and walnuts. ${ }^{21}$ EA was shown to inhibit skin pigmentation resulting from UV irradiation. Results of in vitro experiments have indicated that EA suppresses melanogenesis by inhibiting tyrosinase activity. This inhibition is caused by chelation of the copper atoms on the tyrosinase molecules..$^{22,23}$ One study of 30 females with melasma, ranging in age from 26 to 50 years, treated with plant extracts containing EA found statistically significant reductions in melanin between pre- and posttreatment levels evaluated via a Mexameter (CK Electronic, Ramstein, Germany). ${ }^{21}$ Interpretation of the specific effects of EA is not possible in this study as the EA has been studied as a part of plant extracts that are composed of many other phytochemical subcomponents.

\section{Glabridin}

Glabridin, an active ingredient in licorice extract derived from Glycyrrhiza glabra exerts an anti-inflammatory effect via inhibition of superoxide anion production and cyclooxygenase activity. ${ }^{2}$ In an in vitro study, Yokota et al investigated the inhibitory effects of glabridin on melanogenesis and inflammation by using cultured B-16 murine melanoma cells and guinea pig skin. The study analyzed depigmentation with a colorimeter and in a subsequent process through histochemical analysis of the number of melanocytes. The authors concluded that glabridin inhibits tyrosinase activity but has no effect on DNA synthesis. ${ }^{24}$ Further experimentation is needed to explore the lightening effects of glabridin on humans before assessing its clinical effects.

\section{Hesperidin}

Hesperidin is the predominant flavonoid derived from the peel and membranes of citrus fruits. Flavonoids are naturally occurring phenolic phytochemicals that have been reported to possess a host of biological properties in vitro. ${ }^{25}$ Hesperetin, the aglycone of hesperidin, has been reported to provide health benefits such as antioxidant, anti-inflammatory, anticarcinogenic, and photoprotective effects. ${ }^{25}$ Conflicting data regarding the potential skin-lightening benefits of hesperidin exist in the published literature. Older studies conducted by Zhu and $\mathrm{Gao}^{3}$ demonstrated hesperidin's ability to inhibit melanin synthesis through dose-dependent inhibition of tyrosinase activity in human melanocytes and when applied to the skin of laboratory animals. ${ }^{26}$ Hesperidin was not studied independently, as enhancers were added and thus confounding the interpretation of the results. More recent studies have found that hesperidin induces melanogenesis in murine melanoma cells when added to the culture medium, which, if extrapolated to in vivo conditions, would lead to hyperpigmentation. Furthermore, Usach et $\mathrm{al}^{27}$ found 
hesperidin concentrations of 25 and $50 \mu \mathrm{M}$ induced melanin synthesis and tyrosinase activity in human melanocytes in a concentration-dependent manner. Both these results suggest that hesperidin may increase melanin in human skin. ${ }^{27}$ Taken together, the results are conflicting and it is not clear whether hesperidin may increase or decrease pigmentation. Regardless, clinical studies are needed to assess its response in humans.

\section{Liquiritin}

An active compound of licorice, liquiritin has been evaluated in two clinical studies. One study analyzing the effects of topical liquiritin enrolled 90 patients with melasma who attended the outpatient department of Nishtar Hospital, Pakistan, and treated them once daily for 8 weeks with either $2 \%$ or $4 \%$ liquiritin or $4 \%$ hydroquinone. ${ }^{28}$ The study concluded that $4 \%$ liquiritin showed significantly better results than $2 \%$ liquiritin and $4 \%$ hydroquinone. Some patients used sunscreen while others did not, a variable not considered in the analysis of the results. Nevertheless, the results are similar to another study by Amer and Metwalli ${ }^{29}$ from Egypt. They treated 20 patients who had melasma with $2 \%$ liquiritin cream for 4 weeks. Melasma pigmentation intensity was rated on a five-point scale in relation to the patient's normal facial skin. The size of the lesions was measured directly using a millimeter grid scale. Additionally, clinical and photographic evaluation was performed and the overall response was rated on a scale of excellent, good, fair, or poor. Good to excellent results were seen in 18 out of $20(90 \%)$ patients.

\section{Procyanidin}

A promising therapeutic option in the treatment of pigmentation disorders is oral procyanidin, which is the main active component of Pinus pinaster bark extract. Procyanidin is known to have both antioxidant and antiinflammatory properties but only a few published trials have been conducted regarding the potential benefits of oral procyanidin in melasma. Handog et al conducted a double-blind, placebo-controlled prospective study involving 30 healthy female subjects treated with procyanidin for 30 days. Changes in pigmentation were measured using a Mexameter, the Melasma Area and Severity Index, and a global evaluation by the patient and investigator. The study showed significant improvement in the degree of lightening of melasma in the treatment group. ${ }^{30}$ More recently, in a randomized, double-blind, placebo-controlled trial lasting 8 weeks and involving 60 Filipino patients with bilateral epidermal melasma, Handog et $\mathrm{al}^{30}$ assessed the safety and efficacy of oral procyanidin in combination with vitamins A, C, and E. Mexameter measurements demonstrated a significant decrease in the degree of pigmentation, suggesting that procyanidin with vitamins $\mathrm{A}, \mathrm{C}$, and $\mathrm{E}$ is safe and well tolerated, with minimal adverse events. However, the isolated effects of procyanidin remain unknown and further experimentation is needed.

\section{Silymarin}

Silymarin is a standardized extract derived from the milk thistle plant Silybum marianum and is a natural polyphenolic flavonoid. Silybin is a biologically active component with antioxidant properties. ${ }^{31}$ Silymarin has numerous photoprotective mechanisms; it can reduce and suppress harmful effects of solar UV radiation, such as UV-induced oxidative stress, inflammation, immune responses, and DNA damage as well as the induction of apoptosis. ${ }^{32}$ Choo et al demonstrated the inhibitory effect of silymarin on melanogenesis in a mouse melanocyte cell line, and concluded that silymarin significantly prevented melanin production in a dose-dependent manner, without effects on cell viability. ${ }^{33}$ Also, silymarin inhibited L-DOPA oxidation activity of tyrosinase, the ratelimiting melanogenic enzyme. Furthermore, Western blot analysis indicated that silymarin decreased the expression of tyrosinase protein. This study suggests that silymarin may be useful as a natural skin-lightening agent. Given the previous findings, Altaei ${ }^{34}$ sought to assess the safety and efficacy of topical silymarin cream at two different doses in a double-blind, placebo-controlled study for treatment of 96 melasma patients. Both the silymarin creams were reported to reduce the Melasma Area and Severity Index score to 0, although the photographs shown in the manuscript did not have photographs that were standardized for lighting.

\section{Adverse effects}

Clinical trials testing the safety and efficacy of multiple botanicals revealed that patients had fewer adverse effects in comparison to gold standard therapies. ${ }^{35}$ However, plant extracts are not free of side effects; botanicals may cause allergic reactions and photosensitization. ${ }^{36}$ Plant-derived extracts may cause phytodermatitis, which can be differentiated into nonimmunologic (toxic dermatitis) and immunologic (immediate-type hypersensitivity or allergic contact dermatitis). Serious adverse events, such as toxic epidermal necrolysis, ${ }^{37}$ are rarely reported and occur more frequently with oral and high concentration formulations. ${ }^{8}$ Of note, the US Food and Drug Administration does not require rigorous efficacy and safety testing of botanicals before marketing. ${ }^{38}$ Furthermore, 


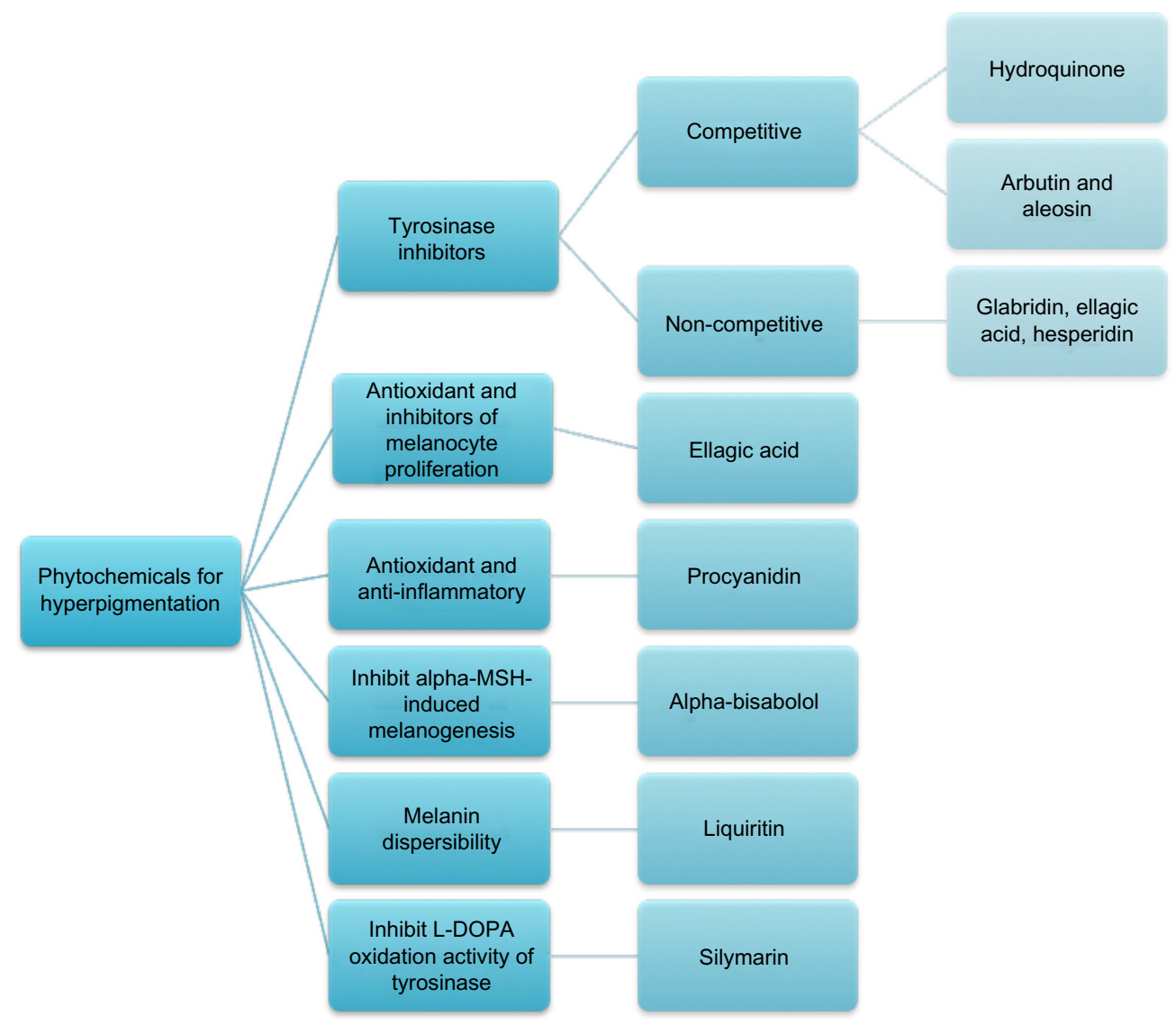

Figure 2 Cosmeceutical mechanism of action for phytochemicals.

Abbreviation: L-DOPA, L-3,4,-dihydroxyphenylalanine; MSH, melanocyte-stimulating hormone.

synthetic therapeutic substances not prescribed or labeled as part of the intended use, such as potent corticosteroids, have been mixed in botanical creams. ${ }^{39,40}$ Adulteration of herbal remedies with corticosteroids exposes consumers to their potential side effects, including atrophy, acneiform eruptions, and dyspigmentation. ${ }^{39}$ Physicians and consumers should remain cautious when considering the use of such products.

\section{Conclusion}

Treating hyperpigmentation poses a challenge to many physicians and an expanded arsenal is necessary to aid in the improvement of topical treatments. A large variety of safe and effective skin-lightening botanicals exist as potential alternatives to current products, such as, hydroquinone (Figure 2). Natural extracts represent a large repository of ingredients for skin-lightening cosmeceuticals. Further studies that integrate phytochemicals with standard therapies are needed for the treatment of hyperpigmentation. Dermatologists and primarycare physicians would benefit from familiarizing themselves with the evidence supporting or refuting the use of botanically derived products for hyperpigmentation treatment, as patients are becoming increasingly interested in natural alternatives.

\section{Disclosure}

The authors report no conflicts of interest in this work.

\section{References}

1. Halder RM, Nootheti PK. Ethnic skin disorders overview. J Am Acad Dermatol. 2003;48(6 Suppl):S143-148.

2. Woolery-Lloyd H, Kammer JN. Treatment of hyperpigmentation. Semin Cutan Med Surg. 2011;30(3):171-175.

3. Zhu W, Gao J. The use of botanical extracts as topical skin-lightening agents for the improvement of skin pigmentation disorders. J Investig Dermatol Symp Proc. 2008;13(1):20-24.

4. Draelos ZD. Skin lightening preparations and the hydroquinone controversy. Dermatol Ther. 2007;20(5):308-313.

5. Sarkar R, Arora P, Garg KV. Skin lightening preparations and the hydroquinone controversy. Dermatol Ther. 2013;6(1):4-11.

6. Levin J, Momin SB. How much do we really know about our favorite cosmeceutical ingredients? J Clin Aesthet Dermatol. 2010;3(2): $22-41$.

7. Bigby M. Snake oil for the 21st century. Arch Dermatol. 1998;134(12): 1512-1514.

8. Fisk WA, Agbai O, Lev-Tov HA, Sivamani RK. The use of botanically derived agents for hyperpigmentation: a systematic review. $J$ Am Acad Dermatol. 2014;70(2):352-365.

9. Chahal DS, Sivamani RK, Isseroff RR, Dasu MR. Plant-based modulation of Toll-like receptors: an emerging therapeutic model. Phytother Res. 2013;27(10):1423-1438.

10. Fisk WA, Lev-Tov HA, Sivamani RK. Botanical and phytochemical therapy of acne: a systematic review. Phytother Res. 2014;28(8): $1137-1152$. 
11. Leo MS, Sivamani RK. Phytochemical modulation of the Akt/mTOR pathway and its potential use in cutaneous disease. Arch Dermatol Res. 2014;306(10):861-871.

12. Sivamani RK, Ma BR, Wehrli LN, Maverakis E. Phytochemicals and naturally derived substances for wound healing. Adv Wound Care (New Rochelle). 2012;1(5):213-217.

13. Jones K, Hughes J, Hong M, Jia Q, Orndorff S. Modulation of melanogenesis by aloesin: a competitive inhibitor of tyrosinase. Pigment Cell Res. 2002;15(5):335-340.

14. Yagi A, Kanbara T, Morinobu N. Inhibition of mushroom-tyrosinase by aloe extract. Planta Med. 1987;53(6):515-517.

15. Choi S, Lee SK, Kim JE, Chung MH, Park YI. Aloesin inhibits hyperpigmentation induced by UV radiation. Clin Exp Dermatol. 2002;27(6):513-515.

16. Lee J, Jun H, Jung E, Ha J, Park D. Whitening effect of alpha-bisabolol in Asian women subjects. Int J Cosmet Sci. 2010;32(4):299-303.

17. Kim S, Lee J, Jung E, et al. Mechanisms of depigmentation by alphabisabolol. J Dermatol Sci. 2008;52(3):219-222.

18. Hori I, Nihei K, Kubo I. Structural criteria for depigmenting mechanism of arbutin. Phytother Res. 2004;18(6):475-479.

19. Maeda K, Fukuda M. Arbutin: mechanism of its depigmenting action in human melanocyte culture. JPharmacol Exp Ther. 1996;276(2):765-769.

20. Boissy RE, Visscher M, DeLong MA. DeoxyArbutin: a novel reversible tyrosinase inhibitor with effective in vivo skin lightening potency. Exp Dermatol. 2005;14(8):601-608.

21. Ertam I, Mutlu B, Unal I, Alper S, Kivcak B, Ozer O. Efficiency of ellagic acid and arbutin in melasma: a randomized, prospective, openlabel study. J Dermatol. 2008;35(9):570-574.

22. Shimogaki H, Tanaka Y, Tamai H, Masuda M. In vitro and in vivo evaluation of ellagic acid on melanogenesis inhibition. Int $J$ Cosmet Sci. 2000;22(4):291-303.

23. Kasai K, Yoshimura M, Koga T, Arii M, Kawasaki S. Effects of oral administration of ellagic acid-rich pomegranate extract on ultravioletinduced pigmentation in the human skin. J Nutr Sci Vitaminol (Tokyo). 2006;52(5):383-388.

24. Yokota T, Nishio H, Kubota Y, Mizoguchi M. The inhibitory effect of glabridin from licorice extracts on melanogenesis and inflammation. Pigment Cell Res. 1998;11(6):355-361.

25. Proteggente AR, Basu-Modak S, Kuhnle G, et al. Hesperetin glucuronide, a photoprotective agent arising from flavonoid metabolism in human skin fibroblasts. Photochem Photobiol. 2003;78(3):256-261.
26. Huang YB, Lee KF, Huang CT, Tsai YH, Wu PC. The effect of component of cream for topical delivery of hesperetin. Chem Pharm Bull (Tokyo). 2010;58(5):611-614.

27. Usach I, Talens-Visconti R, Magraner-Pardo L, Peris JE. Hesperetin induces melanin production in adult human epidermal melanocytes. Food Chem Toxicol. 2015;80:80-84.

28. Zubair S, Mujtaba G. Comparison of efficacy of topical $2 \%$ liquiritin, topical 4\% liquiritin and topical $4 \%$ hydroquinone in the management of melasma. JPAD. 2009;19:158-163.

29. Amer M, Metwalli M. Topical liquiritin improves melasma. Int J Dermatol. 2000;39(4):299-301.

30. Handog EB, Galang DA, de Leon-Godinez MA, Chan GP. A randomized, double-blind, placebo-controlled trial of oral procyanidin with vitamins A, C, E for melasma among Filipino women. Int J Dermatol. 2009;48(8):896-901.

31. Provinciali M, Papalini F, Orlando F, et al. Effect of the silybin-phosphatidylcholine complex (IdB 1016) on the development of mammary tumors in HER-2/neu transgenic mice. Cancer Res. 2007;67(5):2022-2029.

32. Kren V, Walterova D. Silybin and silymarin - new effects and applications. Biomed Pap Med Fac Univ Palacky Olomouc Czech Repub. 2005;149(1):29-41.

33. Choo SJ, Ryoo IJ, Kim YH, et al. Silymarin inhibits melanin synthesis in melanocyte cells. J Pharm Pharmacol. 2009;61(5):663-667.

34. Altaei T. The treatment of melasma by silymarin cream. BMC Dermatol. 2012;12:18.

35. Costa A, Moises TA, Cordero T, Alves CR, Marmirori J. Association of emblica, licorice and belides as an alternative to hydroquinone in the clinical treatment of melasma. An Bras Dermatol. 2010;85(5): 613-620.

36. Reuter J, Merfort I, Schempp CM. Botanicals in dermatology: an evidence-based review. Am J Clin Dermatol. 2010;11(4):247-267.

37. Kokcam I. Toxic epidermal necrolysis probably due to cosmetic cream: a case report. Acta Dermatovenerol Alp Pannonica Adriat. 2009;18(1): 39-42.

38. Thornfeldt C. Cosmeceuticals containing herbs: fact, fiction, and future. Dermatol Surg. 2005;31(7 Pt 2):873-880; discussion 880.

39. Keane FM, Munn SE, du Vivier AW, Taylor NF, Higgins EM. Analysis of Chinese herbal creams prescribed for dermatological conditions. BMJ. 1999;318(7183):563-564.

40. Huang WF, Wen KC, Hsiao ML. Adulteration by synthetic therapeutic substances of traditional Chinese medicines in Taiwan. J Clin Pharmacol. 1997;37(4):344-350.
Botanics: Targets and Therapy

\section{Publish your work in this journal}

Botanics: Targets and Therapy is an international, peer-reviewed, open access journal focusing on the discovery and development of active compounds based upon or found naturally occurring in the plant kingdom that may have therapeutic potential in any disease state. The manuscript management system is completely online and includes a very

\section{Dovepress}

quick and fair peer-review system. Visit http://www.dovepress.com/ testimonials.php to read real quotes from published authors. 